\title{
PROBLEMATIKA PENGEMBANGAN MODUL PEMBELAJARAN BACA TULIS ANAK USIA SEKOLAH DASAR
}

\author{
Rahmah Purwahida \\ Universitas Negeri Jakarta \\ E-mail: rahmah.purwahida@unj.ac.id
}

\begin{abstract}
ABSTRAK
Aktivitas belajar dan pengembangan modul dilakukan dengan pola pembelajaran dan pemberdayaan masyarakat secara terpadu bagi warga belajar berusia dewasa. Pola pembelajaran lainnya untuk menunjang yaitu pembangunan jaringan belajar sehingga warga belajar tidak berhenti belajar setelah program selesai. Dalam proses itu ditelusuri problematika pengembangan modul pembelajaran baca tulis anak usia sekolah dasar. Hasilnya yaitu para warga belajar yang merupakan para orangtua memahami kelambatan pada kemampuan membaca dan menulis anaknya. Kegiatan ini berhasil karena peserta dapat menyusun modul meskipun dalam bentuk sederhana.
\end{abstract}

Kata kunci: problematika, modul, pembelajaran baca tulis, anak

\section{PROBLEMATIC ISSUES IN DEVELOPING TEACHING MODULE FOR PRIMARY STUDENT'S READING AND WRITING}

\begin{abstract}
Learning activities and module development are done with learning patterns and integrated community empowerment for adult learning residents. Another learning pattern to support is the construction of learning networks so that learners do not stop learning after the program is completed. In the process traced the problematic of the development of learning literacy module of elementary school age children. The result is that the learners who are the parents understand the slowness in the ability to read and write their children. This activity works because participants can arrange modules even in simple form.
\end{abstract}

Keywords: problematic issues, modules, literacy learning, children 


\section{PENDAHULUAN}

Persoalan tingkat pendidikan masyarakat yang rendah di daerah Babelan Kota, Bekasi, Jawa Barat yang turut menyumbang persoalan pendidikan yang dihadapai Jawa Barat seharusnya mendapatkan perhatian solutif. Berdasarkan data Badan Pusat Statistik (BPS) menunjukkan rata-rata pendidikan masyarakat di Jawa Barat hanya 6,8 tahun berarti masyarakat Jawa Barat hanya lulusan SD. Hal ini ditegaskan pula oleh Badan Musyawarah (Bamus) Masyarakat Sunda bahwa masalah utama Provinsi Jawa Barat yaitu masalah pendidikan.

Data dari BPS tentang kemampuan baca tulis siswa di Bekasi memang memprihatinkan. Data ini dikuatkan dengan data PISSA yang menyebutkan budaya literasi Indonesia terburuk kedua dari 65 negara yang diteliti. Persoalan lain dalam bidang pendidikan tentang kenyataan siswa SD kesulitan baca tulis saat di kelas rendah (kelas 1-3 SD) sehingga guru-guru SD mengalami kesulitan dalam penerapan Kurikulum 2013. Hal ini terjadi pula di Babelan Kota, Bekasi, Jawa Barat. Data-data ini menegaskan bahwa persoalan literasi di Indonesia perlu terus dicarikan solusinya.

Masyarakat Babelan Kota, Bekasi, Jawa Barat hidup dalam kondisi eknomi lemah. Dalam masyarakat tersebut, terdapat para ibu yang tidak bekerja (berstatus sebagai ibu rumah tangga) dan memiliki banyak waktu luang. Para ibu ini memiliki keinginan untuk membelajarkan baca tulis kepada anaknya. Akan tetapi, mereka tidak memiliki bekal pengetahuan dan keterampilan. Di sisi lain, kondisi perekonomian keluarga mereka lemah sehingga tidak memiliki biaya untuk memasukkan anak-anak mereka ke les/bimbingan baca tulis yang lokasinya juga jauh dari tempat tinggal mereka. Dengan demikian, para ibu ini 
membutuhkan pengetahuan dan keterampilan menyusun bahan ajar dan membelajarkan baca, tulis, dan berhitung (calistung) agar bisa menyelesaikan persoalan-persoalan yang mereka hadapi. Mengubah sebuah produk pendidikan harus menggunakan metode khusus. Tidak hanya berwujud arahan dan larangan, namun dengan cara yang menyenangkan, salah satunya dengan memperhatikan teknik untuk memberikan edukasi.

Tujuan kegiatan ini yaitu untuk (1) mengadakan pelatihan dasar dan lanjutan dalam rangka memberikan pengetahuan dan membekali keterampilan dalam menyusun bahan ajar calistung serta membelajarkannya untuk anak usia sekolah dasar, (2) memfasilitasi pendampingan dan konseling mengenai pengasuhan anak, (3) meningkatkan daya literasi para ibu rumah tangga di Babelan Kota, Bekasi, Jawa Barat melalui pelatihan dan pendampingan, (4) meningkatkan daya literasi anak usia sekolah dasar di Babelan Kota, Bekasi, Jawa Barat melalui pelatihan dan pendampingan, (5) memberdayakan masyarakat untuk tangguh menyelesaikan persoalan hidup; dan (6) membantu pemerintah Jawa Barat dalam pemberantasan buta aksara aksara dan meningkatkan daya listerasi masyarakatnya.

Manfaat kegiatan ini, yaitu (1) memberikan pengetahuan dan membekali keterampilan dalam menyusun bahan ajar calistung serta membelajarkannya untuk anak usia sekolah dasar, (2) memberikan pendampingan dan konseling mengenai pengasuhan anak, (3) meningkatkan daya literasi para ibu rumah tangga di Babelan Kota, Bekasi, Jawa Barat, (4) meningkatkan daya literasi anak usia sekolah dasar di Babelan Kota, Bekasi, Jawa Barat, (5) memberdayakan masyarakat untuk tangguh menyelesaikan persoalan hidup; dan (6) membantu 
pemerintah Jawa Barat dalam pemberantasan buta aksara aksara dan meningkatkan daya listerasi masyarakatnya.

Bahan ajar merupakan rincian spesifikasi isi yang memberikan panduan bagi guru atau dosen dalam hal intensitas cakupan dan jumlah penelitian yang dituntut oleh isi tertentu atau tugas-tugas pedagogis. Wright (1987) mengungkapkan bahwa bahan ajar dapat membantu ketercapaian tujuan, silabus, dan membantu peran guru/dosen dan siswa/mahasiswa dalam proses belajar mengajar. Jadi, bahan ajar atau materi pembelajaran adalah pengetahuan, keterampilan, dan sikap yang harus dipelajari siswa dalam rangka mencapai standar kompetensi yang telah ditentukan. Secara terperinci, jenis-jenis materi pembelajaran terdiri dari pengetahuan (fakta, konsep, prinsip, dan prosedur), keterampilan, dan sikap atau nilai. Bahan ajar merujuk kepada sesuatu yang digunakan dosen untuk memudahkan belajar, sedangkan pengembangan bahan ajar yang dilakukan penulis untuk memberikan sumber masukan berbagai pengalaman yang dirancang untuk meningkatkan belajar bahasa.

Menurut Majid (2006) bahan ajar mempunyai beberapa bentuk, yaitu (a) bahan ajar cetakan seperti handout, modul, buku, lembar kerja siswa, brosur, leaflet, wallchart, foto/gambar, dan model/maket; (b) bahan ajar dengar seperti kaset, radio, piringan hitam, dan cakram digital audio; (c) bahan ajar pandang dengar seperti cakram digital video dan film; dan (d) bahan ajar interaktif seperti cakram digital interaktif.

Kemendiknas (2007) juga merujuk ke UNESCO merumuskan syarat bahan ajar yang baik. syarat-syarat bahan ajar atau buku teks yang berkualitas diuraikan melalui kutipan berikut. Syarat-syarat bahan ajar atau buku teks yang 
berkualitas adalah (1) bahan ajar memiliki peran penting untuk mewujudkan pendidikan yang merata dan berkualitas tinggi, (2) bahan ajar merupakan produk dari proses yang lebih besar dari pengembangan kurikulum, (3) isi bahan ajar memasukkan prinsip-prinsip hak asasi manusia, mengintegrasikan proses pedagogis yang mengajarkan secara damai penyelesaian konflik, kesetaraan gender, nondiskriminasi, praktik-praktik dan sikap-sikap lain yang selaras dengan kebutuhan untuk belajar hidup bersama, (4) bahan ajar memfasilitasi pembelajaran untuk mendapatkan hasil-hasil spesifik yang dapat diukur dengan memperhatikan berbagai perspektif, gaya pembelajaran, dan modalitas berbeda (pengetahuan, keterampilan, dan sikap), (5) memperhitungkan level konseptual, lingkungan linguistik, latar belakang dan kebutuhan pebelajar di dalam membentuk isi dan mendesain model pembelajaran, (6) bahan ajar memfasilitasi pembelajaran yang dapat mendorong partisipasi dan pengalaman secara merata dan setara oleh semua pebelajar yang terlibat dalam proses pembelajaran, dan (7) bahan ajar dapat dijangkau dari sisi biaya, memiliki daya tahan lama, dan dapat diakses oleh semua pembelajar.

Dengan demikian, secara umum ada tiga prinsip yang diperlukan dalam penyusunan bahan ajar. Ketiga prinsip itu adalah relevansi, konsistensi, dan kecukupan. Relevansi artinya keterkaitan atau berhubungan erat. Konsistensi maksudnya ketaatasasan atau keajegan-tetap. Kecukupan maksudnya secara kuantitatif materi tersebut memadai untuk dipelajari. 


\section{METODE}

Kegiatan ini mencakup program belajar kepada para ibu di Babelan Kota Bekasi, Jawa Barat agar mengetahui dan menguasai cara mengajarkan baca tulis kepada anak. Para ibu ini disebut warga belajar. Aktivitas belajar dilakukan dengan pola pembelajaran dan pemberdayaan masyarakat secara terpadu bagi warga belajar berusia dewasa. Pola pembelajaran lainnya untuk menunjang yaitu pembangunan jaringan belajar sehingga warga belajar tidak berhenti belajar setelah program selesai.

Untuk menyelenggarakan program ini dilakukan 8 prinsip utama, sebagai berikut.

1. Konteks sosial yaitu program dikembangkan berdasarkan konteks sosial di Babelan Kota, Bekasi Jawa Barat dan kebutuhan khusus warga belajar.

2. Desain lokal yaitu rancangan kegiatan belajar yang dirancang berdasarkan minat, kebutuhan, masalah, kenyataan warga belajar, dan potensi daerah Babelan Kota, Bekasi Jawa Barat.

3. Proses partisipatif yaitu perencanaan, pelaksanaan dan evaluasi penyelenggaraan program dilaksanakan dengan strategi partisipatif.

4. Fungsionalisasi hasil belajar yaitu hasil belajar dari warga belajar diharapkan dapat memiliki penegetahuan dan keterampilan membelajarkan baca tulis kepada anak.

5. Membangun kesadaran warga belajar untuk memiliki kesadaran dan kepedulian terhadap permasalahan lingkungan untuk melakukan aktivitasnya. 
6. Fleksibilitas, program ini fleksibel sehingga responsif terhadap minat dan kebutuhan belajar serta kondisi lingkungan warga belajar dari waktu ke waktu.

\section{HASIL DAN PEMBAHASAN}

Penelitian pendahuluan dalam bagian penelitian ini menemukan hal-hal sebagai berikut: berdasarkan wawancara kepada 12 siswa SD, 3 orang guru SD, dan 3 pengurus pengajian ibu-ibu di Babelan Kota terungkap bahwa sejumlah ibu terpancing emosi dan melakukan kekerasan kepada anak-anak mereka ketika mencoba mengajarkan calistung atau mencoba membantu mengerjakan tugas sekolah anak (wawancara, Januari 2018). Hal ini disebabkan pengetahuan dan keterampilan membelajarkan calistung dan mendampingi anak mengerjakan tugas sekolah tidak dimiliki para ibu (wawancara dan observasi, Januari-Maret 2018). Dengan demikian, perlu dilakukan pemberdayaan para ibu rumah tangga dalam membangkan pengetahuan dan keterampilan mereka baik dalam mengembangkan bahan ajar membaca, menulis, dan berhitung dan membelajarkannya kepada anak maupun pemberdayaan para ibu dalam pengasuhan anak usia sekolah dasar untuk meningkatkan daya literasi mereka.

Permasalahan yang ada yaitu (1) kemampuan baca tulis siswa di Babelan Kota, Bekasi memperihatinkan; (2) siswa SD kesulitan baca tulis saat di kelas rendah (kelas 1-3 SD) sehingga guru-guru SD kesulitan menerapkan Kurikulum 2013; (3) para ibu rumah tangga tidak memililki pengetahuan maupun keterampilan untuk membelajarkan baca, tulis, berhitung (calistung) kepada anak-anaknya sendiri yang masih SD; serta (4) kekerasan pada anak kerap terjadi 
saat para ibu mencoba mengajarkan calistung atau pada saat mendampingi anak mengerjakan tugas sekolah. Solusi yang ditawarkan yaitu memberikan pelatihan penyusunan bahan ajar calistung dan membelajarkan calistung dengan memanfaatkan kearifan lokal yang ada, memberikan pendampingan dan konseling mengenai pengasuhan anak kepada para ibu rumah tangga, dan memberdayakan kelompok pengajian ibu-ibu untuk menjadi mentor.

Kegiatan ini dilakukan dengan memberikan pengarahan kepada para ibu mengenai modul dan bagaimana mengembangkannya. Pemaparan materi ini dilaksanakan di suatu rumah yang sehari-harinya merupkan rumah Bimbingan Baca Tulis An-Nisa yang merupakan mitra dalam kegiatan ini. Seluruh peserta yang hadir berjumlah 76 orang, terdiri atas 69 orang merupakan para ibu dan 7 orang merupakan nenek-nenek yang mengasuh cucunya dan antusias untuk mengikuti kegiatan ini. Setelah itu, peserta diberikan contoh modul sederhana yang sesuai dengan usia dan perkembangan anak yang diasuhnya. Peserta antusias melihat contoh dan ingin menyusun modul. Akan tetapi, umumnya peserta gagap teknologi sehingga peserta meminta untuk menuliskan karyanya di buku tulis. Peserta pun meminta untuk mengerjakannya di rumah.

Peserta pulang dengan membawa buku dan alat tulis serta contoh modul sederhana. Peserta menyusun modul sederhana. Tim mendampingi proses penulisan modul dengan cara mengunjungi tempat tinggal peserta selama tiga minggu setelah pemaparan. Pada satu minggu pertama kesulitan peserta umumnya karena bingung untuk memulai pertama kali untuk menuliskan modulnya. Pada minggu kedua umumnya, peserta sudah mulai menuangkan idenya ke dalam tulisan. Pada minggu ketiga, 67 peserta berhasil menuliskan 
modul sederhananya sebanyak 10 halaman dengan tulisan tangan dan 2 orang peserta mampu menghasilkan 10 halaman yang diketik oleh yang bersangkutan dengan menggunakan netbook yang difasillitasi tim pengabdian karena kedua peserta ini memiliki keterampilan mengetik. Kedua modul tersebut dapat dilihat pada lampiran 1 dan 2.

Modul yang ditulis peserta kegiatan ini memang masih sederhana dan bersumber dari pengalaman mereka berinteraksi dengan anak-anaknya ketika anak-anaknya mengerjakan tugas atau pekerjaan rumah (PR) dari sekolah. Kegiatan ini berangkai karena terdiri atas beberapa kegiatan, mulai dari pemaparan materi, pendampingan penulisan, dan penyempurnaan modul. Dalam tahap-tahap kegiatan ini terdapat sejumlah kendala namun dapat diatasi.

Awalnya, tujuh prinsip pengembangan bahan ajar berupa modul yang diberlakukan pada peserta (para ibu), yaitu (1) bertahap artinya dilaksanakan mulai dari kelompok dan jenis mata pelajaran sampai dengan menetapkan isi dari setiap mata pelajaran, (2) menyeluruh, artinya dilaksanakan dengan memandang isi setiap pelajaran secara menyeluruh tidak bagian per bagian, (3) sistematik, artinya dilaksanakan dengan memandang isi mata pelajaran sebagai kesatuan utuh dan melalui proses yang berulang-ulang, (4) luwes, artinya dapat menerima hal-hal baru yang belum tercakup dalam isi mata pelajaran pada saat pengimplementasiannya, (5) validitas keilmuan, artinya bahan ajar didasarkan pada tingkat validitas dari topik yang ditata urutannya dan dijabarkan keterhubungannya harus benar-benar dapat dipercaya, (6) berorientasi pada pebelajar, artinya harus sesuai dengan karakteristik pebelajar dan memperhatikan kebutuhan serta perhatian/minat pembelajar, dan (7) berkesinambungan, artinya 
pengembangan bahan ajar merupakan proses yang tidak berhenti sekali jalan, tetapi merupakan proses yang menghubungkan setiap kegiatan pengembangan, yaitu merancang, mengevaluasi, dan memanfaatkan.

Pada tahap selanjutnya, hal-hal yang diperhatikan dalam mengembangkan suatu materi ajar berupa modul ini, yaitu (1) memperhatikan motivasi yang diinginkan pembelajar, (2) kesesuaian materi yang diberikan, (3) mengikuti sutu urutan yang benar, (4) berisikan informasi yang dibutuhkan, (5) adanya latihan praktik, (6) dapat memberikan umpan balik, (7) tersedia tes yang sesuai dengn materi yang diberikan, (8) tersedia petunjuk untuk tindak lanjut, (9) tersedia petunjuk bagi peserta didik (para ibu) untuk tahap-tahap yang dilakukan, dan (10) dapat diingat dan ditransfer.

Kendala-kendala dalam kegiatan ini, antara lain kesibukan para ibu yang menjadi sasaran kegiatan ini. Sulitnya mengumpulkan sasaran kegiatan ini dalam satu tempat karena mereka sibuk mengurus anak dan urusan rumah tangga lainnya. Selain it, para ibu ini canggung bila didekati dengan hal-hal yang bersifat formal. Berdasarkan hal itu, pemaparan kegiatan ini dilakukan pada malam hari dan dengan suasana kekeluargaan sehingga kegiatan ini tidak terkesan menggurui dan bersifat formal. Para ibu tidak mau difoto saat pendampingan penulisan di rumahnya karena mereka tidak ingin situasi kesederhanaan rumahnya diabadikan dan dipubliaksikan. Hal ini menjadi kendala bagi tim pengabdian dalam pelaporan. Namun, tim pengabdian mengatasinya dengan mengikuti permintaan peserta dan menghadirkan hasil karya atau modul sederhana yang disusun oleh peserta. 
Kegiatan ini seungguh bermanfaat bagi para ibu karena berdasarkan pengakuan mereka melalui wawancara, mereka menginginkan kegiatan ini berlanjut karena mereka menyukai kegiatan menulis sebab mereka ingin bisa menghasilkan modul yang bermanfaat untuk anak-anak mereka. Motivasi mereka ini juga dipengaruhi oleh keinginan kuat mereka bisa mengajarkan baca tulis kepada anak-anak mereka dengan modul yang merupakan karya mereka.

\section{KESIMPULAN}

Para warga belajar yang merupakan para orangtua memahami kelambatan pada kemampuan membaca dan menulis anaknya.Sudah seharusnya demikian, dikarenakan ada anak yang lebih cepat, ada yang lebih lambat. Pada proses belajar yang melibatkan anak menjadi pelajar, orangtua harus melihat kondisi individu anak. Kegiatan ini berhasil karena peserta dapat menyusun modul meskipun dalam bentuk sederhana. Oleh sebab itu, kegiatan ini merupakan kegiatan awal untuk memberikan kegiatan lanjutan agar mengembangkan keterampilan sasaran kegiatan ini.

\section{DAFTAR PUSTAKA}

Ansoriyah, S. (2017). Pengaruh pemberian musik klasik terhadap kemampuan menulis berita siswa SMAN 37 Jakarta. Aksis: Jurnal Pendidikan Bahasa dan Sastra Indonesia, 1(1). 104-117. doi.org/10.21009/AKSIS.010106

Kemendiknas. (2007). Modul penyusunan bahan ajar. Jakarta: Kemdiknas.

Majid, Abdul. (2006). Perencanaan pembelajaran. Bandung: Remaja Rosda Karya.

Wright, T. (1987). Roles of teachers and learners. Oxfort: University Press. 